\title{
Can Maternal Vitamin E Supplementation Prevent Lung Hypoplasia in the Nitrofen-Induced Rat Model of Congenital Diaphragmatic Hernia?
}

\author{
DAVID L. BECKMAN, JAMES J. CUMMINGS, LAXMANSA C. KATWA, AND \\ MARVIN E. WHITEHURST \\ Departments of Physiology [D.L.B., J.J.C., L.C.K., M.E.W.] and Pediatrics [J.J.C.], Brody School of \\ Medicine, East Carolina University, Greenville, NC 27834
}

\begin{abstract}
ABSTR
Recent studies suggest a role for antioxidants in the preven-
tion of pulmonary hypoplasia associated with congenital dia-
phragmatic hernia (CDH). We studied the effects of vitamin E in
the nitrofen-rat model of CDH. After an initial fast, timed-
pregnant Sprague-Dawley rats were gavage-fed nitrofen at ges-
tational day 11 (term is $22 \mathrm{~d}$ ). On the same day, one group was
given a s.c. injection of vitamin E in alcohol; a second group was
given an injection of alcohol alone. A third group received no
treatment (control). Fetuses were delivered on day 21 , and static
pressure-volume curves were measured by immersion. Lungs
were analyzed for total DNA and protein content by standard
methods. A total of 203 fetuses were studied. Of 151 nitrofen-
exposed fetuses, $77 \%$ had CDH; $92 \%$ of these were right-sided.
CDH was present in $82 \%$ of vehicle-treated fetuses and $71 \%$ of
vitamin E-treated fetuses ( $p=0.17$ ). Nitrofen-exposed fetuses
\end{abstract}
Congenital diaphragmatic hernia $(\mathrm{CDH})$ is thought to result from failure of the pleuroperitoneal canal to close in utero between 8 and $10 \mathrm{wk}$ of gestation (1). As a result, intraabdominal contents herniate into the thoracic cavity, leading not only to hypoplastic development of the ipsilateral lung but also to abnormal development and function of the heart and the contralateral lung. $\mathrm{CDH}$ occurs in approximately one of every 4000 live births and carries substantial morbidity risks. Approximately $60 \%$ of infants with $\mathrm{CDH}$ will die in the immediate neonatal period, and survivors often have significant, life-long cardiopulmonary dysfunction. Because the defect and the associated maldevelopment occur early during fetal development, it is not surprising that early surgical repair and/or cardiopulmonary "rest" with extracorporeal bypass have not been successful in changing the dismal prognosis (2,3). Fetal

Received April 23, 2004; accepted August 2, 2004.

Correspondence: James J. Cummings, M.D., Department of Pediatrics, Brody School of Medicine, 600 Moye Boulevard, Greenville, NC 27834; e-mail: cummingsj@mail.ecu.edu.

Supported by the Institute of Nutrition, The University of North Carolina, Chapel Hill, NC.

DOI: 10.1203/01.PDR.0000151691.47331.94 not only were smaller than control fetuses but also had disproportionately smaller lungs and poorer lung function, even when $\mathrm{CDH}$ was absent; however, lung function was worse when $\mathrm{CDH}$ was present. Vitamin E treatment did not improve either lung growth or function, although there was a trend toward less $\mathrm{CDH}$. We have shown, for the first time, that the lung hypoplasia seen in nitrofen-exposed rat fetuses is associated with a dramatic reduction in static lung function, even when $\mathrm{CDH}$ is not present. Finally, our findings support the notion that lung hypoplasia in the nitrofen-rat model is independent of $\mathrm{CDH}$ formation. (Pediatr Res 57: 392-395, 2005)

\section{Abbreviation \\ CDH, congenital diaphragmatic hernia}

surgery, although theoretically more promising, carries additional risks and even when technically successful has not been shown to affect outcome in infants with this condition $(4,5)$.

A well-characterized animal model of $\mathrm{CDH}$ and pulmonary hypoplasia involves exposing the pregnant rat to 2,4dichlorophenyl-p-nitrophenylether (nitrofen) before normal diaphragmatic closure (day 17 of gestation) $(6,7)$. In this model, the timing of the fetal exposure has predictable consequences on both the incidence and the location (right versus left) of the diaphragmatic defect. For example, exposing the fetal rat to nitrofen at day 11 of development results in the majority of offspring having a right-sided $\mathrm{CDH}$ (7).

A variety of agents, including dexamethasone, epidermal growth factor, transforming growth factor $\beta 1$, and vitamin $\mathrm{A}$, have developmental and maturational effects on fetal animal lungs, and some, such as dexamethasone, have been shown to partially reverse the effects of nitrofen in animal models $(8,9)$, although lung function was generally not assessed in these studies. This is important because mechanical interventions, such as tracheal ligation, have been shown to increase lung growth but do not improve function (10-13). 
The observation that antioxidants such as glutathione and vitamin $\mathrm{C}$ independently accelerate fetal lung growth has led investigators to examine the effects of other antioxidants, such as vitamin E. Although these investigators were able to show that vitamin $\mathrm{E}$ improved lung growth both in vitro and in vivo, lung function was not studied $(14,15)$. In addition, vitamin $\mathrm{E}$ was given well beyond the teratogenic window of nitrofen exposure, and the positive effects on lung growth were modest. Finally, in one of two previous studies, nitrofen-exposed animals without CDH were excluded (14), and in a later study, although all nitrofen-exposed fetuses were included, those with and without $\mathrm{CDH}$ were not analyzed separately (15). Thus, the effect of vitamin $\mathrm{E}$ on hypoplastic lungs without $\mathrm{CDH}$ could not be discerned. In the present study, we examined the effects of vitamin E, given at the time of nitrofen exposure to maximize teratogenic inhibition, and compared fetuses with and without $\mathrm{CDH}$ to determine the independent effect of nitrofen on lung development. We also report the first study of the effect of vitamin $\mathrm{E}$ on lung function in this model.

\section{METHODS}

Animals. Timed-pregnant Sprague-Dawley rat dams (225-275 g) were gavage-fed nitrofen $(320 \mathrm{mg} / \mathrm{kg}$ ) on gestational day 11 (term is $22 \mathrm{~d}$ ), after an initial fast. (Day 11 was selected to reduce the variability in left versus right-sided $\mathrm{CDH}$.) On the same day, dams were also given a s.c. injection of either vitamin $\mathrm{E}(140 \mathrm{mg} / \mathrm{kg} ; 1 \mathrm{mg}=1 \mathrm{IU})$ in vehicle (alcohol) or vehicle alone. Several pregnant rats received neither nitrofen nor vitamin $\mathrm{E}$ and served as controls. Rat dams were anesthetized with an overdose of pentobarbital on day 21 , and the fetuses were removed by an abdominal incision; fetuses then were individually anesthetized with an overdose of pentobarbital. The study was approved by the Institutional Animal Care and Use Committee.

Agents. Purified Nitrofen (Cerilliant Corp., Round Rock, TX) was mixed with olive oil to a concentration of $100 \mathrm{mg} / \mathrm{mL}$. A commercial preparation of vitamin E that contained primarily $\alpha$-tocopherol (Sigma Chemical Co., St. Louis, MO) was diluted with ethanol to a concentration of $200 \mathrm{mg} / \mathrm{mL}$.

Gross analysis. Rat pups were blotted dry and weighed. The abdomen then was opened by incision, and the presence of $\mathrm{CDH}$ was determined. The trachea then was ligated and cannulated with a 22-G catheter (Angiocath; BectonDickinson, Franklin Lakes, NJ), and static pressure volume curves were measured. Lungs then were removed, separated, weighed, homogenized, and refrigerated for later DNA and protein analyses.

Biochemical analysis. Lungs were initially frozen in liquid nitrogen and stored at $-80^{\circ} \mathrm{C}$ until later homogenized in either $30 \mathrm{~mL}$ (for the normally smaller, left lung) or $40 \mathrm{~mL}$ (for the normally larger, right lung) of PBS. Homogenates then were analyzed for DNA and total protein content. DNA content was determined by a fluorometric method using bisbenzimidole (American Hoechst, Bridgewater, NJ) using commercially available bovine pancreatic DNA standards (Sigma Chemical Co.) (16). Fluorescence was read at Ex 356, Em $458 \mathrm{~nm}$ in a fluorocolorimeter (Molecular Devices, Sunnyvale, $\mathrm{CA}$ ) at $37^{\circ} \mathrm{C}$. Protein content was measured by the Bio-Rad method (Bio-Rad Laboratories, Richmond, CA) (17).

Pulmonary function. Cannulated pups were connected to a calibrated pressure transducer (Grass Instruments Co., Quincy, MA), precalibrated using a water manometer. Static pressure-volume curves were generated by a recently described method using the principle of Archimedes (18). Briefly, the pup was immersed in a saline-filled, $250-\mathrm{mL}$ beaker sitting on an electronic balance, accurate to $\pm 0.0001 \mathrm{~g}$. A three-way stopcock allowed instillation of air into the fetal lungs using a $10-\mathrm{mL}$ glass syringe. Each $1-\mu \mathrm{L}$ change in volume displacement within the pup's lung resulted in a 1-mg change in recorded weight of the system. The lungs were pressurized in 5- $\mathrm{cm}_{2} \mathrm{O}$ increments, until a maximum pressure of $35 \mathrm{~cm} \mathrm{H} \mathrm{H}_{2} \mathrm{O}$ was reached, then deflated in a like manner. The static volume at the first step in deflation $(30 \mathrm{~cm}$ $\mathrm{H}_{2} \mathrm{O}$ ) was taken as a measure of surface tension recoil pressure.

Statistical analysis. Data are reported as mean \pm SD. Groups were compared using unpaired $t$ tests for continuous variables and $\chi^{2}$ analysis for discrete variables, using commercial software (Statview; Abacus Concepts, Berkeley, CA). A $p<0.05$, corrected for multiple comparisons when appropriate, was taken as indicating a significant difference.

\section{RESULTS}

A total of 203 fetuses, born of 22 dams, were studied. Of 151 nitrofen-exposed fetuses, $77 \%$ had $\mathrm{CDH}$; $92 \%$ of these were right-sided, and $5 \%$ were bilateral. The incidence of $\mathrm{CDH}$ was $82 \%$ in control fetuses and $71 \%$ in vitamin E-treated fetuses $(p=0.17)$.

Because the vast majority of $\mathrm{CDH}$ that occurred was rightsided, we excluded fetuses with left-sided CDH (i.e. either isolated or bilateral) from further analysis and compared measures of right lung growth and development. We found that nitrofen-exposed fetuses not only were smaller than nonexposed fetuses but also had disproportionately smaller lungs and poorer lung function, despite higher DNA content relative to lung weight (Table 1). These differences seemed to be due primarily to nitrofen exposure and not the presence of $\mathrm{CDH}$ (Table 2). However, the poorer lung function seen in nitrofenexposed fetuses was even worse when $\mathrm{CDH}$ was present (Table $3)$.

Vitamin E treatment at the time of nitrofen exposure did not seem to improve either lung growth or function. In fetuses without $\mathrm{CDH}$, vitamin $\mathrm{E}$ treatment was associated with significantly higher DNA/protein ratios, suggesting cellular hypoplasia (Table 2). In fetuses with $\mathrm{CDH}$, vitamin $\mathrm{E}$ treatment was associated with higher total lung DNA but no differences in lung weight or function (Table 4).

\section{DISCUSSION}

In a nitrofen model of $\mathrm{CDH}$, we found that exposure at day 11 of gestation in the pregnant rat leads to $72 \%$ of their fetuses having an isolated, right-sided $\mathrm{CDH}$. Previous experience suggested that earlier exposure (i.e. gestational day 8-9) might result in a variable percentage of left- and right-sided $\mathrm{CDH}$, whereas we found that later exposure ensured a more homo-

Table 1. Comparison of control and nitrofen-exposed fetuses, with or without CDH

\begin{tabular}{|c|c|c|c|c|c|c|c|}
\hline & \multirow[b]{2}{*}{$N$} & \multirow[b]{2}{*}{$\begin{array}{l}\text { Body weight } \\
(\mathrm{g})\end{array}$} & \multirow[b]{2}{*}{$\begin{array}{l}\text { Total lung } \\
\text { DNA (mg) }\end{array}$} & \multicolumn{3}{|c|}{ Right lung measurements } & \multirow[b]{2}{*}{$\begin{array}{l}\text { Deflation volume } \\
\text { ( } \mu \mathrm{L} / \mathrm{g} \text { body weight) }\end{array}$} \\
\hline & & & & $\begin{array}{c}\text { Weight/body } \\
\text { weight }(\mathrm{mg} / \mathrm{g})\end{array}$ & $\begin{array}{c}\text { DNA/lung } \\
(\mathrm{mg} / \mathrm{g})\end{array}$ & $\begin{array}{c}\text { DNA/protein } \\
(\mathrm{mg} / \mathrm{g})\end{array}$ & \\
\hline Nitrofen & 78 & $4.45 \pm 0.31^{*}$ & $668 \pm 200^{*}$ & $11 \pm 4^{*}$ & $8.6 \pm 3.3^{*}$ & $213 \pm 77$ & $25 \pm 12 *$ \\
\hline $\mathrm{Nit}+$ Vit E & 64 & $4.35 \pm 0.47^{*}$ & $772 \pm 196^{* \dagger}$ & $12 \pm 5^{*}$ & $9.9 \pm 4.7 * \dagger$ & $281 \pm 83^{*} \ddagger$ & $27 \pm 14 *$ \\
\hline
\end{tabular}

* Significantly different from control, $p<0.0005$, by ANOVA.

$\dagger$ Significantly different from nitrofen alone, $p<0.05$, by ANOVA.

$\ddagger$ Significantly different from nitrofen alone, $p<0.0001$, by ANOVA. 
Table 2. Comparison of control and nitrofen-exposed fetuses, without $\mathrm{CDH}$

\begin{tabular}{|c|c|c|c|c|c|c|c|}
\hline & \multirow[b]{2}{*}{$N$} & \multirow[b]{2}{*}{$\begin{array}{l}\text { Body weight } \\
\text { (g) }\end{array}$} & \multirow[b]{2}{*}{$\begin{array}{l}\text { Total lung } \\
\text { DNA (mg) }\end{array}$} & \multicolumn{3}{|c|}{ Right lung measurements } & \multirow[b]{2}{*}{$\begin{array}{l}\text { Deflation volume } \\
\text { ( } \mu \mathrm{L} / \mathrm{g} \text { body weight })\end{array}$} \\
\hline & & & & $\begin{array}{c}\text { Weight/body } \\
\text { weight (mg/g) }\end{array}$ & $\begin{array}{l}\text { DNA/lung } \\
(\mathrm{mg} / \mathrm{g})\end{array}$ & $\begin{array}{l}\text { DNA/protein } \\
(\mathrm{mg} / \mathrm{g})\end{array}$ & \\
\hline Control & 52 & $5.27 \pm 0.34$ & $906 \pm 195$ & $16 \pm 3$ & $6.3 \pm 1.5$ & $233 \pm 54$ & $51 \pm 7$ \\
\hline Nitrofen & 15 & $4.54 \pm 0.40 *$ & $726 \pm 262 *$ & $12 \pm 3^{*}$ & $7.9 \pm 2.7 *$ & $221 \pm 95$ & $35 \pm 17 *$ \\
\hline $\mathrm{Nit}+$ Vit E & 19 & $4.31 \pm 0.58 *$ & $816 \pm 163$ & $13 \pm 3^{*}$ & $8.7 \pm 1.9 *$ & $306 \pm 80 * \dagger$ & $37 \pm 18 *$ \\
\hline
\end{tabular}

* Significantly different from control, $p<0.005$, by ANOVA.

$\dagger$ Significantly different from nitrofen alone, $p<0.0001$, by ANOVA.

Table 3. Comparison of nitrofen-exposed fetuses with (right only) and without CDH

\begin{tabular}{|c|c|c|c|c|c|c|}
\hline & \multirow[b]{2}{*}{$N$} & \multirow[b]{2}{*}{$\begin{array}{l}\text { Body weight } \\
\text { (g) }\end{array}$} & \multicolumn{3}{|c|}{ Right lung measurements } & \multirow[b]{2}{*}{$\begin{array}{l}\text { Deflation volume } \\
\text { ( } \mu \mathrm{L} / \mathrm{g} \text { body weight })\end{array}$} \\
\hline & & & $\begin{array}{c}\text { Weight } / \text { body } \\
\text { weight }(\mathrm{mg} / \mathrm{g})\end{array}$ & $\begin{array}{c}\text { DNA/lung } \\
(\mathrm{mg} / \mathrm{g})\end{array}$ & $\begin{array}{c}\text { DNA/protein } \\
(\mathrm{mg} / \mathrm{g})\end{array}$ & \\
\hline No $\mathrm{CDH}$ & 34 & $4.41 \pm 0.52$ & $13 \pm 3$ & $8.3 \pm 2.3$ & $269 \pm 96$ & $36 \pm 17$ \\
\hline
\end{tabular}

* Significantly different from no CDH, $p<0.0001$, by ANOVA.

Table 4. Comparison of nitrofen-exposed fetuses with right-sided $\mathrm{CDH}$

\begin{tabular}{|c|c|c|c|c|c|c|c|}
\hline & \multirow[b]{2}{*}{$N$} & \multirow[b]{2}{*}{$\begin{array}{c}\text { Body weight } \\
(\mathrm{g})\end{array}$} & \multirow[b]{2}{*}{$\begin{array}{l}\text { Total lung } \\
\text { DNA (mg) }\end{array}$} & \multicolumn{3}{|c|}{ Right lung measurements } & \multirow[b]{2}{*}{$\begin{array}{l}\text { Deflation volume } \\
\text { ( } \mu \mathrm{L} / \mathrm{g} \text { body weight) }\end{array}$} \\
\hline & & & & $\begin{array}{c}\text { Weight/body } \\
\text { weight }(\mathrm{mg} / \mathrm{g})\end{array}$ & $\begin{array}{l}\text { DNA/lung } \\
(\mathrm{mg} / \mathrm{g})\end{array}$ & $\begin{array}{l}\text { DNA/protein } \\
(\mathrm{mg} / \mathrm{g})\end{array}$ & \\
\hline Nitrofen & 63 & $4.43 \pm 0.29$ & $654 \pm 182$ & $11 \pm 4$ & $8.8 \pm 3.5$ & $212 \pm 72$ & $22 \pm 8$ \\
\hline $\mathrm{Nit}+$ Vit E & 45 & $4.37 \pm 0.41$ & $753 \pm 208 *$ & $12 \pm 6$ & $10.4 \pm 5.3$ & $270 \pm 82$ & $23 \pm 9$ \\
\hline
\end{tabular}

* Significantly different from nitrofen alone, $p<0.01$, by ANOVA.

geneous population of almost exclusively right-sided $\mathrm{CDH}$. Similar to previous reports, we found that nitrofen exposure was associated with generalized poor growth, as measured by total body weight, and disproportionately small lungs with evidence of cellular hypoplasia. For the first time, we also showed that nitrofen exposure led to poor pulmonary mechanical function. We did not find that vitamin E treatment at the time of nitrofen exposure significantly ameliorated any of these effects.

The nitrofen-exposed rat model has been used often to study $\mathrm{CDH}$, but the effect of nitrofen in fetuses without $\mathrm{CDH}$ has not been well studied. This is important, because some of the abnormal lung findings in previous studies of $\mathrm{CDH}$ in this model may have been due to nitrofen exposure per se and not the associated $\mathrm{CDH}$. Our data confirm previous observations that nitrofen can induce pulmonary hypoplasia independent of $\mathrm{CDH}$. This has been previously suggested by others $(19,20)$, although the concept of lung hypoplasia occurring before development of $\mathrm{CDH}$ has been disputed by others. The findings in our study, along with the recent observation that nitrofenexposed fetal lungs show evidence of hypoplasia before the development of $\mathrm{CDH}$ (21), clearly support the concept that lung hypoplasia in $\mathrm{CDH}$ is not a secondary phenomenon. It is possible that the primary defect in nitrofen-induced $\mathrm{CDH}$ is lung hypoplasia and that the diaphragmatic defect may actually be a secondary phenomenon, and some mechanisms by which this might occur have been discussed (22). However, a recent series of studies in mutant mice suggests that the diaphragmatic defect in the nitrofen model is independent of myogenesis and lung formation (23).

We have shown for the first time that the lung hypoplasia seen in the nitrofen model of $\mathrm{CDH}$ is associated with a dramatic reduction in static lung function. Whether this was solely due to the obvious lung hypoplasia or there was also a functional surfactant deficiency could not be discerned by our methods. Although surfactant dysfunction has been shown in human infants with CDH (24) and in some animal models of CDH $(25,26)$, a recent study in the nitrofen-rat model found that surfactant protein expression was not altered in rats with nitrofen-induced $\mathrm{CDH}$ (27). However, in all of these animal studies, only fetuses with $\mathrm{CDH}$ were examined. We found evidence of severe pulmonary hypoplasia in nitrofen-exposed fetuses regardless of $\mathrm{CDH}$, although static lung volume was significantly worse when $\mathrm{CDH}$ was present. We have also shown that nitrofen exposure leads to generalized poor fetal growth, with disproportionately poor lung growth and development. This adds further support to previous observations that the nitrofen model shows a striking similarity to the human phenotype.

Two previous studies $(14,15)$ concluded that vitamin $\mathrm{E}$ had a protective effect on lung growth and development in the nitrofen model of $\mathrm{CDH}$. In those studies, vitamin $\mathrm{E}$ was given to pregnant rats daily for $5 \mathrm{~d}$, beginning $1 \mathrm{wk}$ after exposure to nitrofen. The authors found that treatment with vitamin $\mathrm{E}$ was associated with increased lung weights and total lung DNA but no change in lung DNA concentration or DNA:protein ratios suggesting accelerated growth of the hypoplastic lungs. We also found that vitamin $\mathrm{E}$ treatment resulted in significantly higher total lung DNA, but nitrofen-exposed fetuses still had significantly less total lung DNA than control fetuses. In one of the previous studies, a control group was not included, so the magnitude of the effect of vitamin E supplementation could not be discerned (14). In a more recent study, a control group was included and the effect of vitamin E supplementation was 
actually modest; indeed, in that study, vitamin E-treated, nitrofen-exposed fetuses had significantly lower lung weights, lung DNA, and lung protein than the control fetuses (15). Similar to this study, we were able to show that the improved lung growth seen with vitamin E treatment was actually modest, and these nitrofen-exposed fetuses still had significantly hypoplastic lungs compared with normal fetuses. This was further evident when we examined mechanical function; vitamin E-treated fetuses had static lung volumes no different from control fetuses. It is intriguing to note that there was a trend toward less $\mathrm{CDH}$ in vitamin E-treated fetuses, although this, too, was a modest effect.

There are at least two methodologic differences between our study and the two previous studies noted above. First, the total dose of vitamin E used by us was somewhat lower. We gave a single depot injection of vitamin $\mathrm{E}$, whereas the two previous studies noted above gave several daily doses of vitamin $\mathrm{E}$ intragastrically. Second, the timing of vitamin E supplementation was different. We gave vitamin $\mathrm{E}$ at the time of nitrofen exposure, hypothesizing that if it worked by blocking the teratogenic effects of nitrofen, then the modest effects seen in other studies may have been because vitamin $\mathrm{E}$ was not given until several days after nitrofen exposure. However, our data refute this hypothesis.

Although it is possible that a higher does of vitamin E may have shown more positive effects, this seems unlikely for several reasons. First, the dose of vitamin $\mathrm{E}$ that we used is already large, when one considers that a dose of $3.5 \mathrm{mg} / \mathrm{d}$ is sufficient to maintain normal vitamin $\mathrm{E}$ levels in premature neonates who weigh $<1000 \mathrm{~g}(28)$; we gave a dose that was 10 -fold higher than this to pregnant rats that typically weighed $250 \mathrm{~g}$. Second, although the two previous studies noted above gave 4-20 times as much vitamin E, they still found that vitamin E-treated fetuses were no bigger than control fetuses, a result that we found as well $(14,15)$. Third, we administered the vitamin $\mathrm{E}$ on the same day as the nitrofen, ensuring that the highest concentration of vitamin $\mathrm{E}$ was present during the time when nitrofen should have been inducing its effects.

\section{CONCLUSION}

In conclusion, nitrofen not only is a potent inducer of $\mathrm{CDH}$ in the rat model but also results in significant lung hypoplasia in fetuses without $\mathrm{CDH}$. These effects are only modestly ameliorated by concurrent treatment with vitamin E. Our data add further to the concept that in the nitrofen model of $\mathrm{CDH}$, which shares much homology with the human phenotype, lung hypoplasia may be an entirely separate phenomenon from $\mathrm{CDH}$ formation. This notion has received strong support from the elegant work of Babiuk et al. (23) showing that diaphragmatic defects can occur independent of lung formation. This idea also agrees well with the clinical observations that fetal diaphragmatic repair has not improved survival in cases of $\mathrm{CDH}(4)$ and that lung hypoplasia seen with $\mathrm{CDH}$ is not limited to the ipsilateral lung (1). Further advances in this area will need to uncover the actual mechanism(s) by which lung hypoplasia develops in this disorder.
Acknowledgments. Dr. Reza Sanii offered valuable assistance in the development of the nitrofen model in our laboratory. Sherry Moseley assisted with DNA analyses.

\section{REFERENCES}

1. Davenport M 1999 Diaphragmatic hernia. In: Rennie J, Roberton N (eds) Textbook of Neonatology. Churchill Livingstone, New York, pp 654-662

2. Langer J, Filler RM, Bohn DJ, Shandling B, Ein SH, Wesson DE, Superina RA 1988 Timing of surgery for congenital diaphragmatic hernia: is emergency operation necessary? J Pediatr Surg 23:731-734

3. O'Rourke P, Lillehei C, Crone R, Vacanti J 1991 The effect of extracorporeal membrane oxygenation on the survival of neonates with high risk congenital diaphragmatic hernia: 45 cases from a single institution. J Pediatr Surg 26:147-152

4. Sydorak R, Harrison MR 2003 Congenital diaphragmatic hernia: advances in prenatal therapy. Clin Perinatol 30:465-479

5. Harrison MR, Keller RL, Hawgood SB, Kitterman JA, Sandberg PL, Farmer DL, Lee H, Filly RA, Farrell JA, Albanese CT 2003 A randomized trial of fetal endoscopic tracheal occlusion for severe fetal congenital diaphragmatic hernia. N Engl J Med 349:1916-1924

6. Kluth D, Kangah R, Reich P, Tenbrinck R, Tibboel D, Lambrecht W 1990 Nitrofeninduced diaphragmatic hernias in rats: an animal model. J Pediatr Surg 25:850-854

7. Tenbrinck R, Tibboel D, Gaillard J, Kluth D, Bos AP, Lachmann B, Molenaar JC 1990 Experimentally induced congenital diaphragmatic hernia in rats. J Pediatr Surg 25:426-429

8. Thebaud B, Barlier-Mur AM, Chailley-Heu B, Henrion-Claude A, Tibboel D, DinhXuan AT, Bourbon JR 2001 Restoring effects of vitamin A on surfactant synthesis in nitrofen-induced congenital diaphragmatic hernia in rats. Am J Respir Crit Care Med 164:1083-1089

9. Zgleszewski SE, Cilley RE, Krummel TM, Chinoy MR 1999 Effects of dexamethasone, growth factors, and tracheal ligation on the development of nitrofen-exposed hypoplastic murine fetal lungs in organ culture. J Pediatr Surg 34:1187-1195

10. O'Toole S, Sharma A, Karamanoukian H, Holm B, Azizkhan R, Glick PL 1996 Tracheal ligation does not correct the surfactant deficiency associated with congenital diaphragmatic hernia. J Pediatr Surg 31:546-550

11. Piedboeuf B, Laberge J, Ghitulescu G, Gamache M, Petrov P, Belanger S, Chen MF, Hashim E, Possmayer F 1997 Deleterious effect of tracheal obstruction in type II pneumocytes in fetal sheep. Pediatr Res 41:473-479

12. De Paepe M, Papadakis K, Johnson BD, Luks FI 1998 Fate of the type II pneumocyte following tracheal occlusion in utero: a time-course study in fetal sheep. Virchows Arch 432:7-16

13. Kapur P, Holm BA, Irish MS, Patel A, Glick PL 1999 Tracheal ligation and mechanical ventilation do not improve the antioxidant enzyme status in the lamb model of congenital diaphragmatic hernia. J Pediatr Surg 34:270-272

14. Islam S, Narra V, Cote GM, Manganaro TF, Donahoe PK, Schnitzer JJ 1999 Prenatal vitamin $\mathrm{E}$ treatment improves lung growth in fetal rats with congenital diaphragmatic hernia. J Pediatr Surg 34:172-176, discussion 176-177

15. Gonzalez-Reyes S, Alvarez L, Diez-Pardo JA, Tovar JA 2003 Prenatal vitamin E improves lung and heart hypoplasia in experimental diaphragmatic hernia. Pediatr Surg Int 19:331-334

16. Labarca C, Paigen K 1980 A simple, rapid, and sensitive DNA assay procedure. Anal Biochem 102:344-352

17. Bradford MM 1976 A rapid and sensitive method for the quantitation of microgram quantities of protein utilizing the principle of protein-dye binding. Anal Biochem 72:248-254

18. Suen HC, Losty PD, Donahue PK, Schnitzer JJ 1994 Accurate method to study static volume-pressure relationships in small fetal and neonatal animals. J Appl Physiol 77:1036-1043

19. Iritani I 1984 Experimental study on embryogenesis of congenital diaphragmatic hernia. Anat Embryol (Berl) 169:133-139

20. Guilbert TW, Gebb SA, Shannon JM 2000 Lung hypoplasia in the nitrofen model of congenital diaphragmatic hernia occurs early in development. Am J Physiol 279:L1159-L1171

21. Jesudason E 2002 Challenging embryological theories on congenital diaphragmatic hernia: future therapeutic implications for paediatric surgery. Ann R Coll Surg Engl $84: 252-259$

22. Keijzer R, Liu J, Deimling J, Tibboel D, Post M 2000 Dual-hit hypothesis explains pulmonary hypoplasia in the nitrofen model of congenital diaphragmatic hernia. Am J Pathol 156:1299-1306

23. Babiuk RP, Greer JJ 2002 Diaphragm defects occur in a CDH hernia model independently of myogenesis and lung formation. Am J Physiol 283:L1310L1314

24. Wigglesworth J, Desai R, Guerrini P 1981 Fetal lung hypoplasia: biochemical and structural variations and their possible significance. Arch Dis Child 56:606-615

25. Glick PL, Stannard VA, Leach CL, Rossman J, Hosada Y, Morin FC, Cooney DR, Allen JE, Holm B 1992 Pathophysiology of congenital diaphragmatic hernia II: the fetal lamb CDH model is surfactant deficient. J Pediatr Surg 27:382-387

26. Suen HC, Catlin EA, Ryan DP, Wain JC, Donahoe PK 1993 Biochemical immaturity of lungs in congenital diaphragmatic hernia. J Pediatr Surg 28:471-475

27. Van Tuyl M, Blommaart P, Keijzer R, Wert SE, Ruijter JM, Lamers WH, Tibboel D 2003 Pulmonary surfactant protein A, B, and C mRNA and protein expression in the nitrofen-induced congenital diaphragmatic hernia rat model. Pediatr Res 54:641-652

28. Phillips P, Franck LS, Greene HL 1987 Vitamin E levels in premature infants during and after intravenous multivitamin supplementation. Pediatrics 80:680-683 